GSA Data Repository Material, Formolo et al. (2007)

\title{
I. Methods
}

Core extraction and GC-MS analysis. Samples from the NPC core were collected from the Western Michigan University Core Research Laboratory, and samples from the PC core were obtained from Aurora Energy, Ltd. (Traverse City, MI). The exterior of each sample was rinsed in methanol to remove external contaminants introduced during coring and handling. Powdered rock samples were decarbonated with concentrated sulfurous acid until reaction ceased. Total organic carbon concentrations were determined in triplicate using a Costech ECS140 Elemental Analyzer. Approximately 30 grams of crushed Norwood and Lachine Members of the Antrim Shale from each core were solvent extracted in 3:1 dichloromethane (DCM): methanol $(\mathrm{MeOH})$ for 72 hours in a Soxhlet apparatus. The extract was separated into saturated, aromatic and two polar fractions using $\mathrm{Si}$ gel column chromatography by the successive elution with hexane, toluene, dichloromethane and methanol, respectively. Fractions were dried under a purified $\mathrm{N}_{2}$ stream at room temperature. Total extractable organic matter (EOM) was determined by gravimetric measurements following solvent extraction.

The hexane fraction was analyzed on a HP 6890 gas chromatograph interfaced to a HP 5973 mass selective detector, using helium as a carrier gas. The GC was equipped with a split/splitless injector and a 30m Hewlett-Packard HP-5MS fused silica capillary column $(0.25 \mathrm{~mm}$ i.d., $0.25 \mu \mathrm{m}$ film thickness). Saturated extract samples were redissolved in hexane and automatically injected in volumes of $1.0 \mu \mathrm{L}$ using an inlet temperature of $300^{\circ} \mathrm{C}$. The oven temperature was initially set at $60^{\circ} \mathrm{C}$ for 1.5 minutes followed by an increase of $20^{\circ} \mathrm{C} /$ minute until $130^{\circ} \mathrm{C}$ and then a $2^{\circ} \mathrm{C} /$ minute increase to $300^{\circ} \mathrm{C}$, at which it was held for the remainder of the run. Total run time $=$ 100.50 minutes. The MS source was operated at $250^{\circ} \mathrm{C}$ in El-mode at $70 \mathrm{eV}$ ionization energy.

Biodegradation indices, maturity and source parameters were calculated using extracted ion chromatograms and peak area integration, using $\mathrm{m} / \mathrm{z}=57$ (alkanes and acyclic isoprenoids), $\mathrm{m} / \mathrm{z}=191$ (hopanes), and $\mathrm{m} / \mathrm{z}=217$ (steranes) (Peters and Moldowan, 1993). Biodegradation biomarker indices are listed in Data Repository Table DR1; source and maturity indices are presented in Table DR2.

Water sample collection. Water samples were collected from continuously-producing wells within the Antrim NPT near the location of the PC and NPC0 cores. Temperature and $\mathrm{pH}$ of well waters were measured on site, and averaged $14.4^{\circ} \mathrm{C}$ and 7.2 , respectively. Waters were drawn from within the actively pumping well stream to avoid contact with the atmosphere. Samples of cellular material were collected at each well head by drawing well water into a sterile $60 \mathrm{~mL}$ disposable syringe and filtering through a $0.22 \mu \mathrm{m}$ nominal pore size cellulose acetate filter (Millipore, Billerica, MA) housed in a pre-sterilized $25 \mathrm{~mm}$ Swinnex filter holder. Filters for DNA extraction were frozen on dry ice, transported to the laboratory and maintained at $-80^{\circ} \mathrm{C}$ until processed. Parallel filters for cell counts were fixed on site with $4 \%$ paraformaldehyde in phosphatebuffered saline, and rinsed with 1:1 ethanol/phosphate-buffered saline solution for subsequent direct counts. A total of eight replicate filters from two wells were DAPI stained and examined immediately by epifluoresence microscopy. Cell counts were calculated as the average and standard deviation of 20 field-counts per slide, using a $100 \mu \mathrm{m}$ diameter field area, a $24 \mathrm{~mm}$ diameter filter area, and a total volume of $60 \mathrm{~mL}$ of filtered water sample. The average cell count among all samples was $6 \times 10^{3}$ cells $\mathrm{mL}^{-1}$; the standard deviation was $3.4 \times 10^{3}$ cells $\mathrm{mL}^{-1}$ 
Genomic DNA extraction. Filters were placed in $0.1 \mathrm{M}$ potassium phosphate buffer at $\mathrm{pH} 7.0$, and shaken gently for 5 minutes to remove cells from the surface. Removal of cells from filters was confirmed by microscopic observation of the filters. Cell material was collected by centrifugation, and the protocol for preparation of genomic DNA followed that of (Stout and Nüsslein, 2005), a modification of (Ausubel et al., 1995) with the following modifications: Lysozyme $(300 \mu \mathrm{g} / \mathrm{ml})$ was added followed by sodium dodecyl sulfate $(0.5 \%)$ to facilitate cell lysis, and RNase A $(25 \mu \mathrm{g} / \mathrm{ml})$ was added prior to Proteinase $\mathrm{K}$ addition to remove any co-extracted RNA.

PCR amplification of 16S rRNA genes. Bacterial 16S rRNA genes were amplified from bulk community DNA using Bacteria-specific primers 27f (Delong, 1992) in combination with the universal primer 1492r (Lane et al., 1985) in a $50 \mu \mathrm{L}$ reaction mixture comprising 1X PCR-Buffer, $400 \mathrm{ng} / \mu \mathrm{l}$ bovine serum albumin, $0.25 \mathrm{mM}$ each dNTP, $1 \mathrm{U} / 10 \mu \mathrm{l} \mathrm{Taq}$ polymerase (all from Promega, Madison, $\mathrm{Wl}$ ), $1.5 \mathrm{mM} \mathrm{MgCl} 2$ (Sigma, St. Louis, MO), $0.5 \mu \mathrm{M}$ of each primer (Integrated DNA Technologies, Coralville, IA), and $40 \mathrm{ng}$ DNA template in a final volume of $30 \mu \mathrm{l}$. The PCR conditions for Bacteria consisted of 30 cycles of $95^{\circ} \mathrm{C}$ for $30 \mathrm{sec}, 56^{\circ} \mathrm{C}$ for $30 \mathrm{sec}$, and $72^{\circ} \mathrm{C}$ for 30 sec with an initial denaturation at $95^{\circ} \mathrm{C}$ for 5 minutes, and a final extension at $72^{\circ} \mathrm{C}$ for 7 minutes. PCR amplification of archaeal 16S rRNA genes used the same concentrations of reagents as mentioned above, except an Archaea-specific nested approach was used, with primers $21 \mathrm{f}$ (Delong, 1992) and 1492r followed by $25 f$ (listed in Achenbach and Woese, 1995) and 958r (Delong, 1992). In the first PCR employing primers $21 \mathrm{~F}$ and $1492 \mathrm{R}$, samples were denatured at $95^{\circ} \mathrm{C}$ for $5 \mathrm{~min}$, followed by 25 cycles of 30 seconds each of $94^{\circ} \mathrm{C}, 55^{\circ} \mathrm{C}$, and $72^{\circ} \mathrm{C}$, completed by a final extension step at $72^{\circ} \mathrm{C}$ for 5 minutes. The amplicon was cleaned with the QIAquick PCR purification kit (Qiagen, Valencia, CA), and $1.0 \mu \mathrm{l}$ of cleaned PCR product from the first PCR was used as template for the second PCR in a fresh reaction cocktail identical to the first reaction, but with the internal Archaea-specific primers $25 \mathrm{f}$ and $958 \mathrm{r}$. The second PCR amplified a region of the 16S rRNA gene of around $870 \mathrm{bp}$ in length, and used a program of 30 cycles of $94^{\circ} \mathrm{C}$ for $30 \mathrm{~s}, 55^{\circ} \mathrm{C}$ for $30 \mathrm{~s}, 72^{\circ} \mathrm{C}$ for $30 \mathrm{~s}$, initiated by a denaturation step of $95^{\circ} \mathrm{C}$ for $5 \mathrm{~min}$, and followed by a final extension step at $72^{\circ} \mathrm{C}$ for 5 min. All PCR reactions were performed in a PTC-200 Peltier thermal cycler (MJ Research, Waltham, MA). In order to minimize PCR bias in subsequent cloning steps, three separate reactions were run for each sample and then pooled together before DNA quantification. PCR products were purified with the QIAquick PCR purification kit (Qiagen, Valencia, CA), quantified by comparison to PCR ladder V (PGC Scientifics, Frederick, MD) using a digital imaging system with LabWorks software (UVP, Upland, $\mathrm{CA})$, and were directly sequenced.

Phylogenetic analysis. Amplified 16S rRNA genes were sequenced with a model 3730xI DNA Analyzer (Applied Biosystems, Inc., Foster City, CA). All sequences were manually edited using the software BioEdit v7.0.4 (Hall, 1999), and aligned to the closest relative using ClustalX v1.83 (Thompson et al., 1997). Phylogenetic analyses were restricted to nucleotide positions that could be unambiguously aligned. The sequences were checked for phylogenetic affiliation using the BLAST search program (Altschul et al., 1990) at the National Center for Biotechnology Information (NCBl; www.ncbi.nlm.nih.gov), and sorted based on low BLAST score similarities and discontinuous alignment portions. All sequences were checked for chimeric artifacts using the software Mallard v1.02 (Ashelford et al., 2006), and eleven chimeric 16S rRNA gene sequences were excluded from further phylogenetic analysis. Sequences that showed $\geq 98 \%$ nucleotide sequence identity were considered similar strains of the same phylotype and grouped as a separate sample (i.e. phylotypes) using the software 
DOTUR v1.53 (Schloss et al., 2004). A 16S rRNA gene phylogenetic tree was constructed from the alignments based on the method Minimum Evolution and calculated by the algorithm of the Tamura-Nei model (Tamura and Nei, 1993), using the software MEGA v3.1 (Kumar et al., 2004). Bootstrap confidence values were obtained with 1000 replicates. The tool Classifier and Sequence Match in the Ribosomal Database Project II release 9.37 (Cole et al., 2003) and BLASTn (Altschul et al., 1990) were used to classify the 16S rRNA gene clones and identify the nearest neighbors of the 16S rRNA genes in the GenBank database. The sequences obtained from the clones have been deposited in the GenBank database under accession numbers EF117331 to EF117602.

\section{Methane generation and isotope mass balance models}

Crushed core gas analysis reveals an average $\mathrm{CH}_{4}$ content in rocks from the Antrim

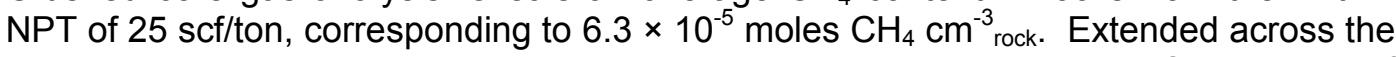
entire Antrim NPT $(160 \mathrm{~km} \times 40 \mathrm{~km} \times 40 \mathrm{~m})$, this yields a total existing $\mathrm{CH}_{4}$ content of $190 \mathrm{Tg} \mathrm{C}\left(\mathrm{CH}_{4}\right)$.

The amount of methane cumulatively produced in the Antrim NPT, and thus the amount subsequently lost during deglaciation, can be estimated from an isotope mass balance model that requires $\mathrm{CH}_{4}$ and all inorganic carbon pools $\left(\mathrm{CO}_{2}, \mathrm{HCO}_{3}{ }^{-}\right.$, and fracture-filling $\mathrm{CaCO}_{3}$ ) to derive from degradation of shale organic matter:

$$
\begin{gathered}
m_{\mathrm{CO} 2} \cdot \delta_{\mathrm{CO} 2}+m_{\mathrm{HCO} 3} \cdot \delta_{\mathrm{HCO} 3}+m_{\mathrm{CaCO} 3} \cdot \delta_{\mathrm{CaCO} 3}+m_{\mathrm{CH} 4} \cdot \delta_{\mathrm{CH} 4}= \\
\left(m_{\mathrm{CO} 2}+m_{\mathrm{HCO} 3}+m_{\mathrm{CaCO} 3}+m_{\mathrm{CH} 4}\right) \cdot \delta_{\mathrm{kerogen}}
\end{gathered}
$$

Using $m_{\mathrm{CO} 2}=1.1 \times 10^{-6}$ moles $\mathrm{cm}^{-3}$ rock $(2 \%$ of total gas $), \delta_{\mathrm{CO} 2}=18 \%$;

$m_{\mathrm{HCO} 3}=2 \times 10^{-6}$ moles $\mathrm{cm}^{-3}{ }_{\text {rock }}\left(40 \mathrm{mM} \mathrm{HCO}_{3}^{-}, 5 \%\right.$ porosity $), \delta_{\mathrm{HCO} 3}=28 \%$;

$m_{\mathrm{CaCO} 3}=193 \times 10^{-6}$ moles $\mathrm{cm}^{-3}$ rock $\left(1.0 \% \mathrm{CaCO}_{3}\right.$, rock density $\left.=1.93 \mathrm{~g} \mathrm{~cm}^{-3}\right)$,

$\delta_{\mathrm{CaCO} 3}=28 \% ; \delta_{\text {kerogen }}=-30 \%$ and $\delta_{\mathrm{CH} 4}=-52 \%$,

yields an estimated methane content of $517 \times 10^{-6}$ moles $\mathrm{cm}^{-3}$ rock to achieve isotope mass balance. Extended across the entire Antrim NPT, this equals a cumulative $\mathrm{CH}_{4}$

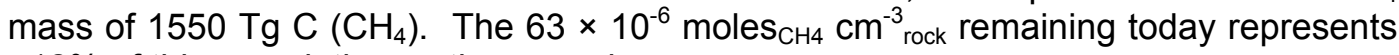
$\sim 12 \%$ of this cumulative methane pool.

A similar isotope mass balance can be constructed from a Rayleigh distillation model, using $R / R_{0}=f^{\alpha-1}$ where $R$ is the present ${ }^{13} \mathrm{C} /{ }^{12} \mathrm{C}$ ratio in the Antrim inorganic carbon pool $\left(\mathrm{CO}_{2}+\mathrm{HCO}_{3}^{-}+\mathrm{CaCO}_{3}\right), \mathrm{R}_{0}$ is the ${ }^{13} \mathrm{C} /{ }^{12} \mathrm{C}$ ratio of the inorganic carbon pool prior to methanogenesis, $\alpha$ is the fractionation associated with $\mathrm{CO}_{2}$-reduction methanogenesis ( $\alpha=0.93$ between the total inorganic carbon pool and methane), and $f$ is the fraction inorganic carbon remaining. Using $R / R_{0}=\left(\delta^{13} C+1000\right) /\left(\delta^{13} C_{0}+1000\right)$, $\delta^{13} \mathrm{C}$ at present for inorganic carbon equals 28\%o, and $\delta^{13} \mathrm{C}_{0}=-30 \%$ (assumed to all derive from shale $\mathrm{OM})$, the fraction of inorganic carbon remaining $\left(\sim 196 \times 10^{-6}\right.$ moles $\mathrm{cm}^{-3}{ }_{\text {rock }}$ ) is $44 \%$ of the initial inorganic carbon pool. $56 \%$ has been converted into methane, yielding a cumulative methane pool of $260 \times 10^{-6}$ moles $\mathrm{cm}^{-3}$ rock. Extended across the entire Antrim NPT, this equals $780 \mathrm{Tg} \mathrm{C}$ as $\mathrm{CH}_{4}$. The $6.3 \times 10^{-5}$ moles $_{\mathrm{CH} 4}$ $\mathrm{cm}^{-3}$ rock remaining today represents $\sim 25 \%$ of this cumulative methane pool. A closedsystem Rayleigh isotope distillation approach, which does not accommodate sustained production of $\mathrm{CO}_{2}$ or methanogenesis via mechanisms other than $\mathrm{CO}_{2}$ reduction, likely yields a severe underestimate of $\mathrm{CH}_{4}$ production and $\mathrm{CO}_{2}$ loss.

A third means to estimate the cumulative original mass of biogenic $\mathrm{CH}_{4}$ in the Antrim employs the difference in extract yield measured in the PC and NPC cores. When normalized to TOC content, the biodegraded core reflects a loss of 50 
$\mathrm{mg}_{\text {extract }} / \mathrm{g}_{\text {Tос. }}$. If the loss of these hydrocarbons resulted entirely in the conversion to methane and $\mathrm{CO}_{2}$ as suggested by methanogenic decomposition of hexadecane, this would equal to generation of a cumulative pool of $440 \times 10^{-6} \mathrm{moles}_{\mathrm{CH}_{4}} / \mathrm{cm}^{3}$ rock and $134 \times$ $10^{-6}$ moles $\mathrm{CO} 2_{2} / \mathrm{cm}^{3}$ rock. Extended across the entire Antrim NPT, this equals $1320 \mathrm{Tg} \mathrm{C}$ as $\mathrm{CH}_{4}$. In this estimate, the remaining pool of Antrim $\mathrm{CH}_{4}$ is nearly $20 \%$ of the initial pool. The total $\mathrm{CH}_{4}$ addition to the atmosphere is calculated using $1 \mathrm{ppbv}=2.86 \mathrm{Tg} \mathrm{C}\left(\mathrm{CH}_{4}\right)$.

\section{Minimum maintenance energy calculations}

Direct counts of Antrim natural gas well waters collected from the NPT indicate a freefloating population of $(1 \pm 0.3) \times 10^{4}$ cells $\mathrm{mL}^{-1}$, with an average diameter of $1.5 \mu \mathrm{m}$. Using cell biomass (in pg C $\mu \mathrm{m}^{-3}$ ) $=0.09 \times \mathrm{V}^{0.9}$ (Norland, 1993), we estimate a cellular biomass in the Antrim NPT of $1.5 \times 10^{-10} \mathrm{~g}_{\mathrm{C}-\text { biomass }} \mathrm{cm}^{-3}$ rock. Using a minimum maintenance energy requirement equivalent to $0.14 \mathrm{~kJ} \mathrm{~mol}^{-1} \mathrm{C} \mathrm{hr}^{-1}$ (Scholten and Conrad, 2000), we estimate a total community maintenance energy demand of $1.54 \times$ $10^{-8} \mathrm{~kJ} \mathrm{~cm}^{-3}$ rock $\mathrm{yr}^{-1}$. Lower maintenance energy demand may be indicated for in situ subsurface communities (D'Hondt et al., 2002; Biddle et al., 2006); however, freefloating cells may also represent only a small fraction of the subsurface Antrim community.

Methanogenic hydrocarbon decomposition can be written (for hexadecane) as:

$$
4 \mathrm{C}_{16} \mathrm{H}_{34}+30 \mathrm{H}_{2} \mathrm{O} \rightarrow 49 \mathrm{CH}_{4}+15 \mathrm{CO}_{2}
$$

Estimated Gibbs free energy yield for this reaction, at concentrations of reactants and products measured in enrichment cultures, is $-1596 \mathrm{~kJ} /$ reaction (Zengler et al., 1999),

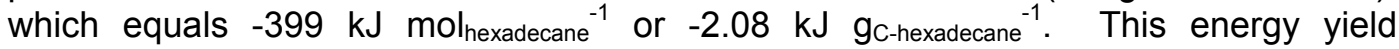
specifically relates to culture conditions described by Zengler et al. (1999) where activities of reactants and products were known. Energy yields for conditions in the Antrim subsurface would need to be modified to reflect in situ conditions where $\mathrm{CH}_{4}$, $\mathrm{CO}_{2}$ and hydrocarbon activities may be different. Community maintenance energy demand divided by free energy yield gives a rate of shale OM degradation of $7.4 \times 10^{-9}$ $\mathrm{gc}_{\mathrm{c}} \mathrm{cm}_{\mathrm{rock}}{ }^{-3} \mathrm{yr}^{-1}$, if the free energy change for methanogenic decomposition of hexadecane is representative of total shale OM. At this rate, 20.9 million years would be required to remove all OM from a rock containing $8 \%$ total organic carbon $(0.154$ gтос $\mathrm{cm}^{-3}$ ).

The time required to generate the present pool of methane in the Antrim shale $\left(6.3 \times 10^{-5}\right.$ moles $\left._{\mathrm{CH} 4} \mathrm{Cm}_{\text {rock }}^{-3}\right)$ can be estimated from the rate of shale OM degradation, using the stoichiometry of the hexadecane decomposition reaction (49 moles $\mathrm{CH}_{4}$ produced per 64 moles hydrocarbon-C degraded). Hydrocarbon degradation at a rate of $7.4 \times 10^{-9} \mathrm{gc} \mathrm{cm}_{\mathrm{rock}}{ }^{-3} \mathrm{yr}^{-1}$ equals a methane production rate of $4.7 \times 10^{-10}$ moles $_{\mathrm{CH} 4} \mathrm{~cm}$ rock $^{-3} \mathrm{yr}^{-1}$. It would require $133 \mathrm{kyr}$ to generate $6.3 \times 10^{-5}$ moles $_{\mathrm{CH} 4} \mathrm{~cm}^{-3}$ rock (the modern inventory of Antrim methane), or 0.55-1.09 Myr to generate the estimated (440-517) $\times$ $10^{-6}$ moles $_{\mathrm{CH} 4} \mathrm{~cm}^{-3}$ rock cumulatively produced in the rock.

\section{References for data repository material}

Achenbach, L., and Woese, C., 1995, Appendix 11: 16S and 23S rRNA-like primers: in Robb, F.T., Place, A.R., Sowers, K.R., Schreier, H.J., DasSarma, S., and Fleischmann, E.M., eds., Archaea: a Laboratory Manual-Methanogens: Plainview, New York, Cold Spring Harbor Laboratory Press, p. 269-273.

Adams, M.A., G.E. Eddy, J.L. Hewitt, J.N. Kirr, and C.T. Rightmire, 1984, Geologic overview, coal resources, and potential methane recovery from coalbeds of the northern Appalachian coal basin-Pennsylvania, Ohio, Maryland, West Virginia, 
and Kentucky, in C.T. Rightmire, G.E. Eddy, and J.N. Kirr, eds., Coalbed methane resources of the United States: AAPG Studies in Geology 17, p. 15-4 Altschul, S.F., Gish, W., Miller, W., Myers, E.W., and Lipman, D.J., 1990, Basic Local Alignment Search Tool: Journal of Molecular Biology, v. 215, p. 403-410.

Ashelford, K.E., Chuzhanova, N.A., Fry, J.C., Jones, A.J., and Weightman, A.J., 2006, New screening software shows that most recent large 16S rRNA gene clone libraries contain chimeras: Applied and Environmental Microbiology, v. 72, p. 5734-5741.

Ausubel, F.M., Brent, R., Kingston, R.E., Moore, D.D., Seidman, J.G., Smith, J.A., and Struhl, K., editors, 1995, Short Protocols in Molecular Biology (third edition): New York, John Wiley \& Sons, $1512 \mathrm{p}$.

Ayers Jr., W.B., 1986. Coal occurrences of the Tongue River Member, Fort Union Formation, Powder River Basin, Wyoming. Geological Survey of Wyoming Report of Investigations. v. 35, p. 1-21

Biddle, J.F., Lipp, J.S., Lever, M.A., Lloyd, K.G., Sørensen, K.B., Anderson, R., Fredricks, H.F., Elvert, M., Kelly, T.J., Schrag, D.P., Sogin, M.L., Brenchley, J.E., Teske, A., House, C.H., and Hinrichs, K.-U., 2006, Heterotrophic Archaea dominate sedimentary subsurface ecosystems off Peru: Proceedings of the National Academy of Sciences, v. 103, p.3846-3851.

Claypool G., Threlkeld C., Magoon L., 1980, Biogenic And Thermogenic Origins Of Natural-Gas In Cook Inlet Basin, Alaska, AAPG Bulletin-American Association Of Petroleum Geologists 64 (8): 1131-1139.

Cole, J.R., Chai, B., Marsh, T.L., Farris, R.J., Wang, Q., Kulam, S.A., Chandra, S., McGarrell, D.M., Schmidt, T.M., Garrity, G.M., and Tiedje, J.M., 2003, The Ribosomal Database Project (RDP-II): previewing a new autoaligner that allows regular updates and the new prokaryotic taxonomy: Nucleic Acids Research, v. 31, p. 442-443.

Dando, P.R., Bussmann, I., Niven, S.J., Ohara, S.C.M., Schmaljohann, R., and Taylor, L.J., 1994, A methane seep area in the Skagerrak, the habitat of the Pogonophore Siboglinum-Poseidon and the bivalve mollusik Thyasira-Sarsi: Marine Ecology-Progress Series, v. 107, p. 157-167.

Delong, E.F., 1992, Archaea in coastal marine environments: Proceedings of the National Academy of Sciences of the United States of America, v. 89, p. 56855689.

D'Hondt, S., Rutherford, S., and Spivack, A.J., 2002, Metabolic activity of subsurface life in deep-sea sediments, Science, v. 295, p.2067-2070.

Elliot, T., Ballentine, C.J., Onions, R.K., and Ricchiuto, T., 1993, Carbon, helium, neon and argon isotopes in a Po Basin (Northern Italy) natural-gas field: Chemical Geology, v. 106, p. 429-440.

Garcia-Garcia, A., Garcia-Gil, S., and Vilas, F., 2003, Monitoring the Spanish gas fields in the Ria de Vigo (1991-2001): Geo-Marine Letters, v. 23, p. 200-206.

Hall, T.A., 1999, BioEdit: a user-friendly biological sequence alignment editor and analysis program for Windows 95/98/NT: Nucleic Acids Symposium Series, v. 41, p. 95-98.

Hildenbrand A, Krooss BM, Busch A, Gaschnitz R, 2006, Evolution of methane sorption capacity of coal seams as a function of burial history - a case study from the Campine Basin, NE Belgium, International Journal Of Coal Geology 66 (3): 179203

Iversen, N., and Jorgensen, B.B., 1985, Anaerobic methane oxidation rates at the sulfate methane transition in marine-sedimetns from Kattegat and Skagerrak (Denmark): Limnology and Oceanography, v. 30, p. 944-955.

Johnson, V.G., Graham, D.L., and Reidel, S.P., 1993, Methane in Columbia River Basalt aquifers - isotopoic and geohydrologic evidence for a deep coal-bed 
gas-source in the Columbia Basin, Washington: AAPG Bulletin-American Association of Petroleum Geologists, v. 77, p. 1192-1207.

Kenduc and Pezdic (2005) Velenje Basin, Slovenia, mixed gas, coal, Geochemical Journal 39 (5) 397-409 Martini, A.M., Walter, L.M., Budai, J.M., Ku, T.C.W., Kaiser, C.J., and Schoell, M., 1998, Genetic and temporal relations between formation waters and biogenic methane: Upper Devonian Antrim Shale, Michigan Basin, USA: Geochimica et Cosmochimica Acta, v. 62, p. 1699-1720.

Kumar, S., Tamura, K., and Nei, M., 2004, MEGA3: Integrated software for molecular evolutionary genetics analysis and sequence alignment: Briefings in Bioinformatics, v. 5, p. 150-163.

Lamarre, R.A. 2003, Hydrodynamic and stratigraphic controls for a large coalbed methane accumulation in Ferron coals of east-central Utah. International Journal of Coal Geology, v. 56 (1-2), p. 97-110.

Lane, D.J., Pace, B., Olsen, G.J., Stahl, D.A., Sogin, M.L., and Pace, N.R., 1985, Rapid-determination of the 16s ribosomoal-RNA sequences for phylogentic analyses: Proceedings of the National Academy of Sciences of the United States of America, v. 82, p. 6955-6959.

Martens, C.S., Kelley, C.A., Chanton, J.P., and Showers, W.J., 1992 Carbon and Hydrogen Isotopic Characterization of Methane from Wetlands and Lakes of the Yukon-Kuskokwin Delta, Western Alaska. Journal of Geophysical ResearchAtmosphers, v. 97 (D15), p. 16689-16701.

Martini, A.M., Walter, L.M., Budai, J.M., Ku, T.C.W., Kaiser, C.J., and Schoell, M., 1998, Genetic and temporal relations between formation waters and biogenic methane: Upper Devonian Antrim Shale, Michigan Basin, USA: Geochimica et Cosmochimica Acta, v. 62, p. 1699-1720.

Nakagawa et al (2002) Eastern Siberia Production of methane from alassesin eastern Siberia: Implications from its $\mathrm{C}-14$ and stable isotopic composition. Global Biogeochemical Cycles 16 (3), Art. No. 1041

Norland, S., 1993, The relationship between biomass and volume of bacteria, in Kemp, P.F., Sherr, B.F., Sherr, E.B., and Cole, J.J., eds., Handbook of methods in aquatic microbial ecology: Boca Raton, Florida, Lewis Publishers, p. 303-309

Peters, K.E., and Moldowan, J.M., 1993, The Biomarker Guide: Interpreting Molecular Fossils in Petroleum and Ancient Sediments: Englewood Cliffs, NJ, PrenticeHall, 363 p.

Rice, D.D., Clayton, J.L., Pawlewicz, M.J., 1989, Characterization of coal-derived hydrocarbons and source-rock potential of coal beds, San Juan Basin, New Mexico and Colorado, U.S.A. International Journal of Coal Geology. 13, v. p. 597-626.

Savoie, S.J., 2002, Positive effects of glacially induced isostatic rebound on Bellingham Basin coal/shale and its implication for enhanced natural gas production. abstract, Geological Society of America $98^{\text {th }}$ Annual Meeting (Cordilleran Section).

Schloss, P.D., Larget, B.R., and Handelsman, J., 2004, Integration of microbial ecology and statistics: a test to compare gene libraries: Applied and Environmental Microbiology, v. 70, p. 5485-5492.

Scholten, J.C.M., and Conrad, R., 2000, Energetics of syntrophic propionate oxidation in defined batch and chemostat cocultures: Applied and Environmental Microbiology, v. 66, p. 2934-2942.

Schroot, B.M., Klaver, G.T., and Schuttenhelm, R.T.E., 2005, Surface and subsurface expressions of gas seepage to the seabed - examples from the Southern North Sea: Marine and Petroleum Geology, v. 22, p. 499-515.

Scott, A.R., Kaiser, W.R., Ayers Jr., W.B., 1994, Thermogenic and secondary biogenic gases, San Juan basin, Colorado and New Mexico - implications for coalbed 
gas producibility. AAPG Bulletin. v. 76, p. 1186-1209.

Shurr and Ridgley (2002) , Denver Basin - Niobrara Formation, early-generation unconventional shallow biogenic gas, chalks on the eastern margin Unconventional shallow biogenic gas systems, AAPG Bulletin, vol. 86, 19391969.

Stout, L.M., and Nüsslein, K., 2005, Shifts in rhizoplane communities of aquatic plants after cadmium exposure: Applied and Environmental Microbiology, v. 71, p. 2484-2492.

Tamura, K., and Nei, M., 1993, Estimation of the number of nucleotide substitutions in the control region of mitochondrial-DNA in humans and chimpanzees: Molecular Biology and Evolution, v. 10, p. 512-526.

Thielemann et al (2004), Ruhr Basin, Germany, mixed gas, coal, Organic Geochemistry 35 (11-12) 1537-1549

Thompson, J.D., Gibson, T.J., Plewniak, F., Jeanmougin, F., and Higgins, D.G., 1997, The CLUSTAL_X windows interface: flexible strategies for multiple sequence alignment aided by quality analysis tools: Nucleic Acids Research, v. 25, p. 4876-4882.

Zengler, K., Richnow, H.H., Rossello-Mora, R., Michaelis, W., and Widdel, F., 1999, Methane formation from long-chain alkanes by anaerobic microorganisms: Nature, v. 401, p. 266-269. 
TABLE DR1: SAMPLE DEPTH, TOC, EXTRACTION YIELDS, AND BIODEGRADATION INDICES

\begin{tabular}{|c|c|c|c|c|c|c|c|c|c|c|c|}
\hline \multirow[b]{2}{*}{ Sample name } & \multirow{2}{*}{$\begin{array}{l}\text { Depth } \\
(\mathrm{m})\end{array}$} & \multirow{2}{*}{$\begin{array}{c}\text { TOC } \\
\text { (wt. \%) }\end{array}$} & \multirow{2}{*}{$\begin{array}{c}\text { Extractable OM } \\
\left(\mathrm{mg}_{\mathrm{extract}} / \mathrm{g}_{\mathrm{rock}}\right)\end{array}$} & \multirow{2}{*}{$\begin{array}{c}\text { Extract yield } \\
\left(\mathrm{mg}_{\text {extract }} / \mathrm{g}_{\mathrm{TOC}}\right)\end{array}$} & \multicolumn{2}{|c|}{$\underline{n \text {-alkanes }}$} & \multicolumn{5}{|c|}{ acyclic isoprenoids } \\
\hline & & & & & $\Sigma n \mathrm{C}_{14}-n \mathrm{C}_{18}{ }^{*}$ & $\Sigma n \mathrm{C}_{19}-n \mathrm{C}_{36}{ }^{*}$ & norpristane* & pristane* & phytane* & $\mathrm{Pr} / n-\mathrm{C}_{17}{ }^{\dagger}$ & $\mathrm{Ph} / n-\mathrm{C}_{18} \S$ \\
\hline \multicolumn{12}{|c|}{ non-producing core } \\
\hline NPC L-1 ${ }^{\dagger}$ & 658 & 4.6 & 285 & 190 & 621 & 808 & 375 & 138 & 95 & 0.79 & 0.58 \\
\hline NPC L-2 & 667 & 5.3 & 185 & 117 & 529 & 883 & 296 & 114 & 87 & 0.61 & 0.53 \\
\hline NPC N-1 & 695 & 5.3 & 219 & 110 & 638 & 1324 & 329 & 125 & 97 & 0.86 & 0.51 \\
\hline NPC N-2 & 698 & 6.2 & 162 & 87 & 1476 & 1556 & 603 & 218 & 142 & 0.52 & 0.43 \\
\hline $\begin{array}{l}\text { average NPC } \\
\text { producing core }\end{array}$ & & $5.3 \pm 0.6$ & $213 \pm 54$ & $126 \pm 44$ & $816 \pm 443$ & $1143 \pm 357$ & $401 \pm 140$ & $149 \pm 47$ & $105 \pm 25$ & $0.70 \pm 0.16$ & $0.51 \pm 0.06$ \\
\hline PC L-1 & 242 & 6.9 & 218 & 89 & 21 & 136 & 122 & 53 & 36 & 7.36 & 4.27 \\
\hline PC L-2 & 251 & 5.8 & 143 & 81 & 48 & 235 & 175 & 82 & 44 & 5.04 & 2.48 \\
\hline PC N-1 & 263 & 9.9 & 195 & 60 & 214 & 739 & 227 & 93 & 69 & 1.2 & 0.77 \\
\hline PC N-2 & 265 & 11.1 & 291 & 75 & 52 & 586 & 649 & 243 & 132 & 3.46 & 2.5 \\
\hline average $\mathrm{PC}$ & & $8.4 \pm 2.5$ & $212 \pm 61$ & $76 \pm 12$ & $83 \pm 88$ & $424 \pm 285$ & $293 \pm 242$ & $118 \pm 85$ & $70 \pm 44$ & $4.27 \pm 2.60$ & $2.51 \pm 1.43$ \\
\hline
\end{tabular}

The Antrim Shale Formation includes, from the base, the Norwood Member (black shale), the Paxton Member (lime mudstone and gray shale), the Lachine Member (black shale) and Upper Antrim (interbedded black and gray shale). "L-" samples are from Lachine Member, "N-" samples are from the Norwood Member.

*abundance normalized to C29 20S diasterane.

${ }^{\dagger} \mathrm{Pr} / \mathrm{n}-\mathrm{C} 17=$ pristane/C17 n-alkane.

${ }^{\S} \mathrm{Ph} / \mathrm{n}-\mathrm{C} 18=$ phytane/C18 n-alkane. 
TABLE DR1 (continued): BIODEGRADATION INDICES ${ }^{*}$

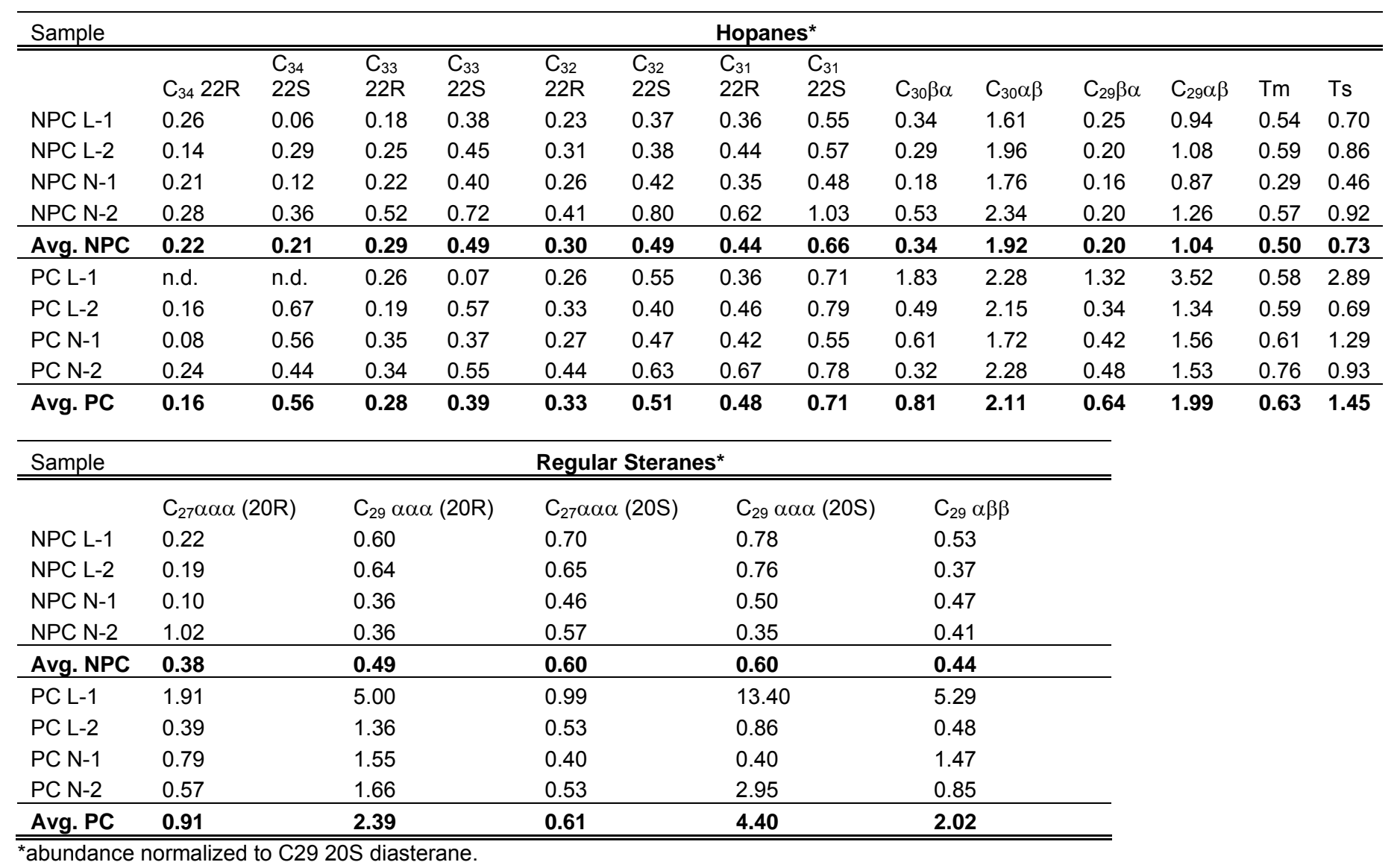


TABLE DR2. SOURCE AND MATURITY INDICES

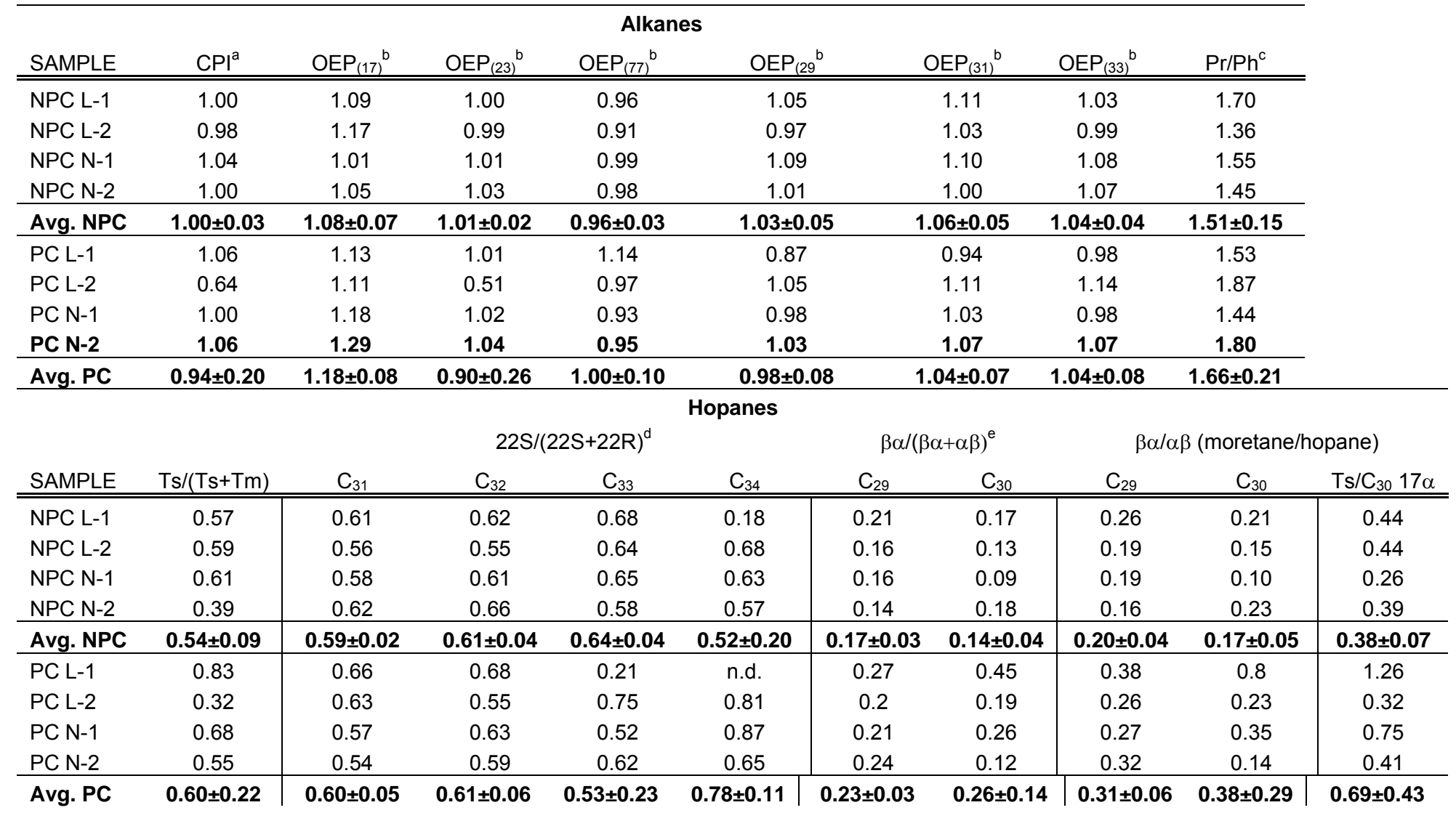




\section{TABLE DR2. SOURCE AND MATURITY INDICES (continued)}

\begin{tabular}{|c|c|c|c|c|c|c|c|c|c|c|c|c|}
\hline \multirow[b]{3}{*}{ SAMPLE } & \multicolumn{11}{|c|}{ Steranes } & \multirow{3}{*}{$\begin{array}{c}\mathrm{C}_{27} \\
\text { diasterane } \\
\beta \alpha / \alpha \beta \\
\end{array}$} \\
\hline & \multicolumn{2}{|c|}{$20 S /(20 S+20 R)^{f}$} & \multicolumn{3}{|c|}{$20 S /(20 S+20 R)^{g}$} & \multicolumn{6}{|c|}{$\mathrm{C}_{27} /\left(\mathrm{C}_{27}+\mathrm{C}_{29}\right)$} & \\
\hline & $\mathrm{C}_{27} \alpha \alpha \alpha$ & $\mathrm{C}_{29} \alpha \alpha \alpha$ & $\begin{array}{c}\mathrm{C}_{27} \text { (dia) } \\
\alpha \beta \\
\end{array}$ & $\begin{array}{c}\mathrm{C}_{27} \\
\text { (dia) } \beta \alpha\end{array}$ & $\mathrm{C}_{29}$ (dia) & $\begin{array}{l}\mathrm{C}_{27} \text { (dia)+ } \\
\mathrm{C}_{27} \text { (reg) } \\
\end{array}$ & $\begin{array}{l}\mathrm{C}_{29} \text { (dia)+ } \\
\mathrm{C}_{29} \text { (reg) } \\
\end{array}$ & $\begin{array}{c}\left(\text { Dia } a_{\text {total }}+\right. \\
\left.\text { Reg }_{\text {total }}\right) \\
\end{array}$ & diasteranes & $\begin{array}{c}\mathrm{C}_{27} \text { (dia)/ } \\
\mathrm{C}_{27} \text { (reg) }\end{array}$ & $\begin{array}{c}\mathrm{C}_{29} \text { (dia)/ } \\
\mathrm{C}_{29} \text { (reg) }\end{array}$ & \\
\hline NPC L-1 & 0.76 & 0.56 & 0.47 & 0.54 & 0.56 & 0.67 & 0.49 & 0.56 & 0.5 & 1.99 & 0.95 & 1.69 \\
\hline NPC L-2 & 0.78 & 0.54 & 0.59 & 0.66 & 0.59 & 0.7 & 0.49 & 0.58 & 0.54 & 2.35 & 0.95 & 2.45 \\
\hline NPC N-1 & 0.83 & 0.58 & 0.47 & 0.61 & 0.53 & 0.73 & 0.59 & 0.64 & 0.44 & 2.69 & 1.42 & 1.82 \\
\hline NPC N-2 & 0.36 & 0.49 & 0.50 & 0.57 & 0.45 & 0.67 & 0.54 & 0.6 & 0.46 & 1.2 & 2.00 & 1.67 \\
\hline Avg. NPC & $0.68 \pm 0.22$ & $0.54 \pm 0.04$ & $0.51 \pm 0.06$ & $0.60 \pm 0.05$ & $0.53 \pm 0.06$ & $0.69 \pm 0.03$ & $0.53 \pm 0.05$ & $0.60 \pm 0.03$ & $0.49 \pm 0.04$ & $2.06 \pm 0.64$ & $1.33 \pm .050$ & $1.91 \pm 0.37$ \\
\hline PC L-1 & 0.34 & 0.73 & 0.85 & 0.40 & 0.53 & 0.6 & 0.07 & 0.19 & 0.69 & 1.49 & 0.08 & 0.83 \\
\hline PC L-2 & 0.58 & 0.39 & 0.47 & 0.64 & 0.53 & 0.63 & 0.41 & 0.49 & 0.45 & 1.69 & 0.7 & 2.08 \\
\hline $\mathrm{PC} \mathrm{N}-1$ & 0.34 & 0.71 & 0.39 & 0.48 & 0.55 & 0.51 & 0.21 & 0.28 & 0.41 & 1.05 & 0.27 & 1.81 \\
\hline $\mathrm{PC} \mathrm{N}-2$ & 0.48 & 0.64 & 0.49 & 0.63 & 0.56 & 0.71 & 0.25 & 0.4 & 0.6 & 2.42 & 0.33 & 1.53 \\
\hline Avg. PC & $0.44 \pm 0.12$ & $0.62 \pm .016$ & $0.55 \pm .020$ & $0.54 \pm .012$ & $0.54 \pm 0.02$ & $0.61 \pm 0.08$ & $0.24 \pm 0.14$ & $0.34 \pm 0.13$ & 0.540 .13 & $1.66 \pm 0.57$ & $0.35 \pm 0.26$ & $1.56 \pm 0.54$ \\
\hline
\end{tabular}

${ }^{\mathrm{a}} \mathrm{CPI}=2\left[\left(\mathrm{C}_{23}+\mathrm{C}_{25}+\mathrm{C}_{27}+\mathrm{C}_{29}\right] /\left[\mathrm{C}_{22}+\left(\mathrm{C}_{24}+\mathrm{C}_{26}+\mathrm{C}_{28}\right)+\mathrm{C}_{30}\right]^{21}\right.$

${ }^{\mathrm{b}} \mathrm{OEP} \mathrm{P}_{\mathrm{x}}=\left[\mathrm{C}_{(\mathrm{x}-2)}+6 \mathrm{C}_{\mathrm{x}}+\mathrm{C}_{(\mathrm{x}+2)}\right] /\left[4 \mathrm{C}_{(\mathrm{X}-1)}+4 \mathrm{C}_{(\mathrm{x}+1)}\right]^{21}$

${ }^{\mathrm{c}} \mathrm{Pr} / \mathrm{Ph}=$ pristane/phytane ${ }^{21}$

${ }^{\mathrm{d}} 22 \mathrm{~S} /(22 \mathrm{~S}+22 \mathrm{R})=17 \alpha(\mathrm{H}), 22 \beta(\mathrm{H})-22 \mathrm{~S}$ homohopane/[17 $\alpha(\mathrm{H}), 22 \beta(\mathrm{H})-22 \mathrm{~S}$ homohopane $+17 \alpha(\mathrm{H}), 22 \beta(\mathrm{H})-22 \mathrm{R}$ homohopane] ${ }^{21}$

${ }^{\mathrm{e}} \beta \alpha /(\beta \alpha+\alpha \beta)=17 \beta(\mathrm{H}), 21 \alpha(\mathrm{H})$ hopane $/\left[17 \beta(\mathrm{H}), 21 \alpha(\mathrm{H})\right.$ hopane $+17 \alpha(\mathrm{H}), 21 \beta(\mathrm{H})$ hopane ${ }^{21}$

${ }^{\mathrm{f}} 20 \mathrm{~S} /(20 \mathrm{~S}+20 \mathrm{R})=5 \alpha(\mathrm{H}), 14 \alpha(\mathrm{H}), 17 \alpha(\mathrm{H})-20 \mathrm{~S}$ stigmastane/[5 $\alpha(\mathrm{H}), 14 \alpha(\mathrm{H}), 17 \alpha(\mathrm{H})-20 \mathrm{~S}$ stigmastane $+5 \alpha(\mathrm{H}), 14 \alpha(\mathrm{H}), 17 \alpha(\mathrm{H})-20 \mathrm{R}$ stigmastane $]^{21}$

${ }^{\mathrm{g}} 20 \mathrm{~S} /(20 \mathrm{~S}+20 \mathrm{R})=\mathrm{C}_{29} 13 \beta(\mathrm{H}), 17 \alpha(\mathrm{H})-20 \mathrm{~S}$ diasterane/ $\left[\mathrm{C}_{29} 13 \beta(\mathrm{H}), 17 \alpha(\mathrm{H})-20 \mathrm{~S} \text { diasterane }+\mathrm{C}_{29} 13 \beta(\mathrm{H}), 17 \alpha(\mathrm{H})-20 \mathrm{R} \text { diasterane }\right]^{21}$ 


\begin{tabular}{|c|c|c|c|}
\hline & \multicolumn{3}{|c|}{$\begin{array}{c}\text { TABLE DR3. BIOGENIC NATURAL-GAS PRODUCTION UNDER FORMERLY } \\
\text { GLACIATED OR PERIGLACIAL TERRAINS }\end{array}$} \\
\hline & Basin & location & reference \\
\hline 1 & Alberta & Alberta (Canada) & Adams et al., (1984); Mclntosh et al. (2004) \\
\hline 2 & Anadarko & OK (USA) & McIntosh et al. (2004) \\
\hline 3 & Appalachian & NY-PA-OH-WV-KY (USA) & McIntosh et al. (2004) \\
\hline 4 & Bellingham & WA (USA) & Savoie et al., (2002) \\
\hline 5 & Campine & Belgium & Hildenbrand et al. (2006) \\
\hline 6 & Columbia & WA (USA) & Johnson et al. (1993) \\
\hline 7 & Cook Inlet & AK (USA) & Claypool et al. (1980) \\
\hline 8 & Denver & CO (USA) & Shurr and Ridley (2002) \\
\hline 9 & Dnieper-Donets & Ukraine & Mclntosh et al. (2004) \\
\hline 10 & Eastern Siberia & Russia & Nakagawa et al., (2002) \\
\hline 11 & Forest City & MO-KS (USA) & Mclntosh et al. (2004) \\
\hline 12 & Illinois & IL-IN-KY (USA) & McIntosh et al. (2004) \\
\hline 13 & Kattegat & Denmark & Iversen and Jorgensen (1985) \\
\hline 14 & Michigan & MI (USA) & McIntosh et al. (2004); Martini et al., (1998) \\
\hline 15 & Po & Italy & Elliot et al. (1993) \\
\hline 16 & Powder River & WY-MT (USA) & Ayers (1986) \\
\hline 17 & Pripyat & Belarus & Mclntosh et al. (2004) \\
\hline 18 & Ria de Vigo & Spain & Garcia-Garcia et al. (2003) \\
\hline 19 & Ruhr & Germany & Thielemann et al., (2004) \\
\hline 20 & San Juan & NM-CO (USA) & Rice et al. (1989); Scott et al. (1994) \\
\hline 21 & Skagerrak & Denmark & Dando et al. (1994); Iversen and Jorgensen (1985) \\
\hline 22 & Silesian & Poland & Kotarba and Rice (2001) \\
\hline 23 & Southern North Sea & Germany, Netherlands & Schroot et al., (2005) \\
\hline 24 & Timan-Pechora & Russia & Mclntosh et al. (2004) \\
\hline 25 & Valenje & Slovenia & Kenduc and Pezdic (2005) \\
\hline 26 & Wasatch Plateau & UT (USA) & Lamarre (2003) \\
\hline 27 & Williston & MT (USA), AB (Canada) & McIntosh et al. (2004) \\
\hline 28 & Yukon & Canada & Martens et al. (1992) \\
\hline
\end{tabular}




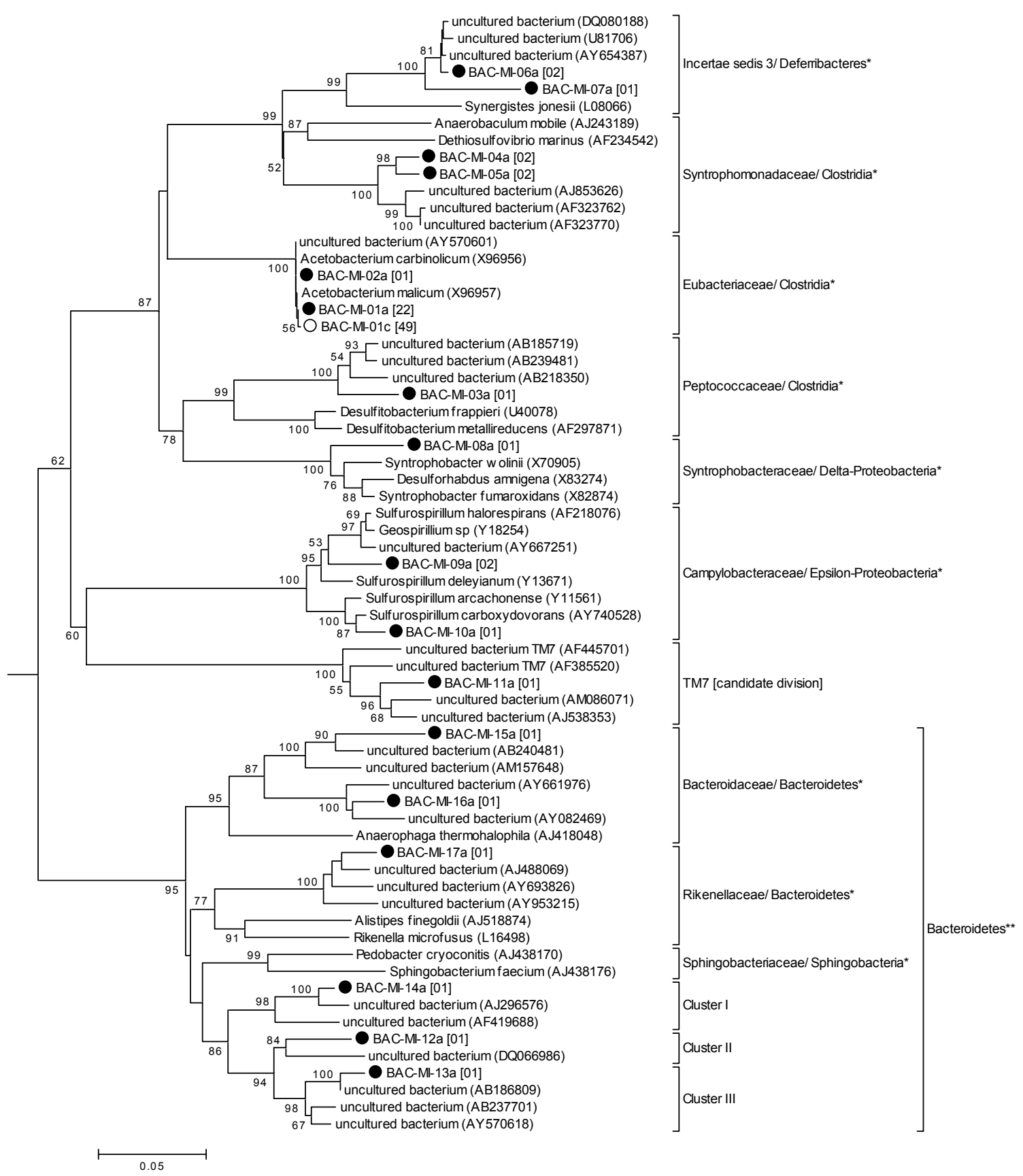

Figure DR1. Phylogenetic relationship and distribution of bacterial clones as identified by family/class $\left({ }^{*}\right) /$ phylum $\left({ }^{* *}\right)$. The comparative analysis was inferred by Minimum Evolution analysis of aligned 16S rRNA gene sequences from 91 bacterial clones compared with public nucleotide databases. Clones are designated by the prefixes $\bullet$ and $\circ$ (reflecting two different Antrim wells adjacent to PC core), followed by the number of representatives [in brackets] in their respective affiliation. The scale-bars represent $5 \%$ estimated sequence divergence. Bootstrap values shown are the percentage of occurrences for nodes with $\geq 50 \%$ support based on an analysis of 1000 iterations. 

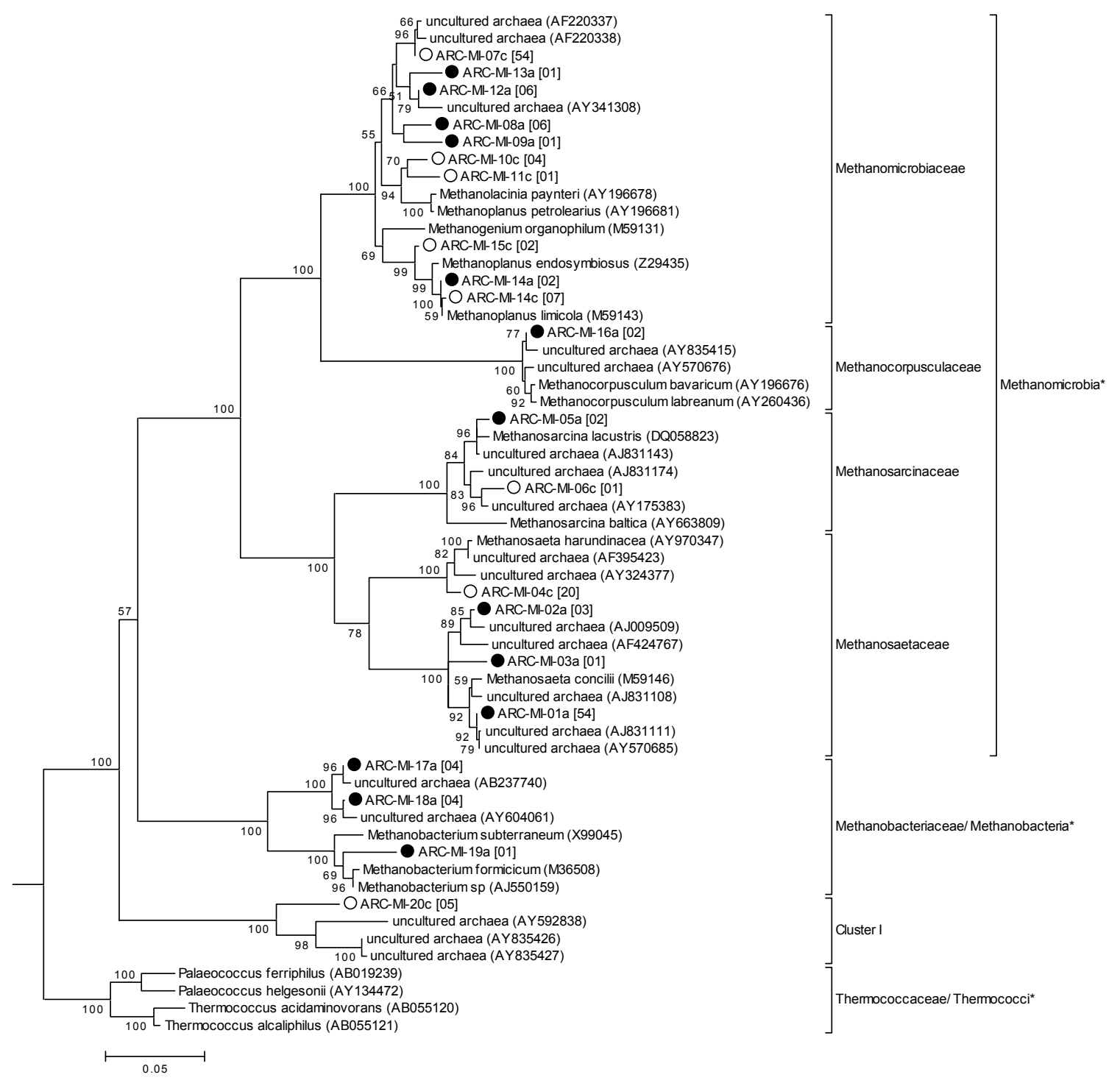

Figure DR2. Phylogenetic relationship and distribution of archaeal clones as identified by family/class $\left({ }^{*}\right) /$ phylum $\left({ }^{* *}\right)$. The comparative analysis was inferred by Minimum Evolution analysis of aligned 16S rRNA gene sequences from 181 archaeal clones compared with public nucleotide databases. Clones are designated by the prefixes $\bullet$ and $\circ$ (reflecting two different Antrim wells adjacent to PC core), followed by the number of representatives [in brackets] in their respective affiliation. The scale-bars represent $5 \%$ estimated sequence divergence. Bootstrap values shown are the percentage of occurrences for nodes with $\geq 50 \%$ support based on an analysis of 1000 iterations. 